\title{
Using Metaphors to Explain Immunotherapy to Cancer Patients
}

\author{
Rachel S. Hianik', Mehmet A. Bilen ${ }^{1,2}$, Ragini R. Kudchadkar'1,2, Margie D. Dixon', Melinda L. Yushak ${ }^{1,2}$, \\ Rebecca D. Pentz', 2* \\ 'Winship Cancer Institute, USA \\ ${ }^{2}$ Emory University School of Medicine, USA
}

\section{Article Info}

\section{Article Notes}

Received: September 20, 2019

Accepted: November 27, 2019

\section{*Correspondence:}

Dr. Rebecca D. Pentz, Professor of Research Ethics, 1760

Haygood Dr. NE Suite East 340, Atlanta, GA 30322, USA;

Telephone No: 1 (404) 778-5694; Fax No: 1 (404) 778-3366;

Email: rpentz@emory.edu.

${ }^{\circledR} 2019$ Pentz RD. This article is distributed under the terms of the Creative Commons Attribution 4.0 International License.

\section{Key Words:}

Immunotherapy

Metaphor

Communication

Oncology

Innovative Treatment

Health Literacy

\section{Abstract}

Background: Immunotherapy is continually being integrated into cancer care, but there is no research on communication strategies to explain it. We examine how metaphors are being used in clinical oncology to describe immunotherapy to patients.

Methods: We observed and audio-recorded 33 first-time conversations about immunotherapy. We took note of each metaphor used in each conversation and conducted a follow-up interview to assess patient understanding of the metaphor used.

Results: Metaphors were used and understanding was assessed 43 times in the 33 conversations about immunotherapy. We describe 14 metaphors used to describe four immunotherapy topics. Patients understood the metaphors $54 \%$ of the time.

Conclusion: Metaphors are being used by providers as a way to describe immunotherapy in clinical oncology. We hope that the examples we provide can be adapted and expanded by other oncologists to assist them in communication with patients about immunotherapy.

\section{Introduction}

Immunotherapy is a promising cancer therapy that has become standard treatment for various sites including melanoma, nonsmall cell lung cancer, and renal cell carcinoma ${ }^{1}$. Although the use of immunotherapy is constantly expanding in cancer care, there is a lack of research on how providers can best communicate information about this treatment to patients. If patients do not understand the language used, it jeopardizes their ability to give informed consent and has been associated with poor adherence and suboptimal health outcomes ${ }^{2}$. Therefore, it is necessary to identify effective communication strategies for providers to describe immunotherapy in ways that patients can understand.

Metaphors are words or phrases used in a non-literal sense, and in oncology are often used as a communication tool ${ }^{3,4}$. We previously described how metaphors were used in clinical oncology to describe molecular testing ${ }^{5}$. We now report how metaphors are used to describe immunotherapy. Our hope is that the metaphors we describe here can be adapted by other oncologists to assist them in communication about immunotherapy.

\section{Methods}

\section{Recruitment}

This study was approved by Emory University's Institutional 
Review Board (IRB00091198). Providers and patients signed informed consents. Oncologists in the melanoma, genitourinary, gastrointestinal, lung and breast clinics were asked to identify eligible patients during their clinics between September 2016 and October 2017. Eligible patients included anyone having a first-time conversation about immune checkpoint inhibitors with his/her provider who were fluent in English. In order to have a consistent sample, we only observed conversations about immune checkpoint inhibitors, that is, the type of immunotherapy that blocks the proteins that keep the immune system from attacking the cancer.

\section{Procedure}

We report here data from a larger study on patients' perceptions of immunotherapy. For the larger study, the Research Assistant (RA) observed and audio recorded the patient/provider conversations about immunotherapy and queried patient views on and understanding of immunotherapy and its side effects. For this study, the RA took note by hand of any metaphor used so that he/she could ask the patient about the metaphor in the interview. We defined metaphor as a comparison of one thing to another in a way this is not literally true. If the metaphor was used more than once in a conversation, it was counted as one instance of use. Directly following the conversation or within one week by phone, the RA interviewed each participant. The interview for the parent study consisted of 7 questions, querying the patients' perceptions of immunotherapy and its side effects. The one question analyzed for this report about metaphors was "What do you think the provider meant when he/she said that 'insert example of metaphor.' Can you explain this in your own words?"

\section{Analysis}

Both the patient/provider conversation and follow-up interview audio-recordings were transcribed. Participant understanding of each metaphor was determined by two independent coders as correct or incorrect compared to how the metaphor was used by the provider. The two independent coders each listened to the audio recording of the physician/patient conversation to determine what the provider meant by the metaphor. There were no disagreements about the providers' meanings. They then each independently determined if the patient's definition in his or her own words matched the meaning intended by the provider. The coders had 3 disagreements that were resolved by consensus. Descriptive statistics were used.

\section{Results}

\section{Participants}

Thirty-three patients participated. Five refused for an $87 \%(33 / 38)$ response rate. Reasons for declining included feeling sick, lacking interest, and not having time. Participant demographics are listed in Table 1 and the nine providers' demographics in Table 2.

\section{Metaphor Use}

Metaphors were used and understanding was assessed 43 times in the 33 conversations with many providers using more than one metaphor per conversation. Fourteen examples of metaphors were grouped into four topics: how immunotherapy works against cancer, how cancer evades the immune system, different immunotherapy drugs, and side effects (Table 3). To describe how immunotherapy works against cancer, providers used six different metaphors. Most commonly, providers used the metaphor "releasing the brakes" to explain how immunotherapy frees the immune system to fight the cancer. Although this metaphor was the most frequently used (18 times), it was

Table 1. Participant Demographic Characteristics

\begin{tabular}{|c|c|c|c|}
\hline & Characteristic & $\mathrm{N}=33$ & $\%$ \\
\hline Disease Site & $\begin{array}{l}\text { Melanoma } \\
\text { Genitourinary } \\
\text { Gastrointestinal } \\
\text { Breast } \\
\text { Aerodigestive }\end{array}$ & $\begin{array}{c}19 \\
6 \\
4 \\
3 \\
1\end{array}$ & $\begin{array}{c}58 \\
18 \\
12 \\
9 \\
3\end{array}$ \\
\hline Gender & $\begin{array}{l}\text { Male } \\
\text { Female }\end{array}$ & $\begin{array}{l}17 \\
16\end{array}$ & $\begin{array}{l}52 \\
49\end{array}$ \\
\hline Age & Mean (range) & $55(31-79)$ & - \\
\hline Ethnicity & $\begin{array}{l}\text { White/Caucasian } \\
\text { Other }^{\text {a }}\end{array}$ & $\begin{array}{c}27 \\
6\end{array}$ & $\begin{array}{l}82 \\
18\end{array}$ \\
\hline Native Language & $\begin{array}{l}\text { English } \\
\text { Spanish }\end{array}$ & $\begin{array}{c}32 \\
1\end{array}$ & $\begin{array}{c}97 \\
3\end{array}$ \\
\hline Education Level & $\begin{array}{l}\text { Less than High School degree } \\
\text { High School or Associate's degree } \\
\text { Undergraduate degree } \\
\text { Graduate degree } \\
\text { Refuse to Answer }\end{array}$ & $\begin{array}{c}3 \\
13 \\
8 \\
8 \\
1\end{array}$ & $\begin{array}{c}9 \\
39 \\
24 \\
24 \\
3\end{array}$ \\
\hline Annual Income & $\begin{array}{l}<\$ 50,000 \\
\$ 50,000-\$ 100,000 \\
\$ 100,000-\$ 150,000 \\
\text { Refuse to Answer } \\
\text { Missing }\end{array}$ & $\begin{array}{c}10 \\
11 \\
3 \\
6 \\
3\end{array}$ & $\begin{array}{c}30 \\
33 \\
9 \\
18 \\
9\end{array}$ \\
\hline
\end{tabular}

*Non-white participants included five Black /African American participants and one Hispanic/Latino participant.

Table 2. Provider Demographic Characteristics

\begin{tabular}{|l|c|c|c|}
\hline \multicolumn{1}{|c|}{ Site } & Age & Years of Practice & Gender \\
\hline \multirow{2}{*}{ Breast } & 41 & $10-15$ & $\mathrm{~F}$ \\
& 36 & $5-10$ & $\mathrm{~F}$ \\
\hline \multirow{2}{*}{ Gastrointestinal } & 41 & $0-5$ & $\mathrm{M}$ \\
& 41 & $5-10$ & $\mathrm{~F}$ \\
\hline Genitourinary & 34 & $0-5$ & $\mathrm{M}$ \\
\hline Lung & 48 & $10-15$ & $\mathrm{M}$ \\
\hline \multirow{3}{*}{ Melanoma } & 69 & $30-40$ & $\mathrm{~F}$ \\
& 40 & $0-5$ & $\mathrm{~F}$ \\
\hline
\end{tabular}


Table 3. Figurative Language Used to Describe Immunotherapy Topics

\begin{tabular}{|c|c|c|}
\hline Topic & Description & Exemplary Quote \\
\hline \multirow[t]{6}{*}{$\begin{array}{l}\text { How Immunotherapy } \\
\text { Works Against Cancer }\end{array}$} & Release the Brakes & $\begin{array}{l}\text { Those drugs will go to your immune system and release the brake. Think of the immune } \\
\text { system like a truck and we want this truck to hit the cancer cells and then kill them, but } \\
\text { unfortunately the cancer is hitting the brakes and because of this the immune system is } \\
\text { unable to kill it. And then we realized if you are able to release the brakes and make the } \\
\text { immune system stronger, the better we will be able to fight the cancer. }\end{array}$ \\
\hline & $\begin{array}{l}\text { Rev Up the Immune } \\
\text { System }\end{array}$ & $\begin{array}{l}\text { So immunotherapy is basically drugs that rev up the immune system in some way, so that } \\
\text { rather than killing off cancer cells directly, it's harnessing your body's immune system to } \\
\text { fight the cancer itself. }\end{array}$ \\
\hline & Refuel the Gas & $\begin{array}{l}\text { So we see immune cells in your melanoma, but they're not working. So this kind of refuels } \\
\text { the gas because cancer cells have a way of kind of sucking the gas out of the tumor. }\end{array}$ \\
\hline & Unmask the Cancer & $\begin{array}{l}\text { But the body doesn't fight the cancer because cancer tricks the body into thinking it's part } \\
\text { of itself and so what the medication does is that it unmasks the cancer so the immune } \\
\text { system can recognize it and fight it. }\end{array}$ \\
\hline & $\begin{array}{l}\text { Wake Up the Immune } \\
\text { System }\end{array}$ & $\begin{array}{l}\text { So when we give you the immunotherapy drug, what the drug does is it will go into your } \\
\text { body, identify the immune cells in your body, and then wake them up. Because part of the } \\
\text { reason why cancer develops and grows is that your immune system does not recognize } \\
\text { the cancer cells as abnormal. }\end{array}$ \\
\hline & $\begin{array}{l}\text { Supercharge the } \\
\text { Immune } \\
\text { System }\end{array}$ & $\begin{array}{l}\text { The immune system is then re-energized and can re-engage to go after the cancer cells. } \\
\text { Now, that is great when they go after the cancer cells...you supercharge the immune } \\
\text { system. }\end{array}$ \\
\hline \multirow[t]{5}{*}{$\begin{array}{l}\text { How Cancer Evades the } \\
\text { Immune System }\end{array}$} & $\begin{array}{l}\text { Blinds the Immune } \\
\text { System }\end{array}$ & $\begin{array}{l}\text { Unfortunately the immune system is not doing anything to the cancer. Because right now, } \\
\text { the cancer is the enemy, but they are sitting right next to each other, and they couldn't do } \\
\text { anything. We realized the reason that they couldn't do anything was because the cancer } \\
\text { makes the immune system blind. }\end{array}$ \\
\hline & Cancer Cloaks Itself & $\begin{array}{l}\text { Part of the reason why cancer develops and grows is that your immune system does not } \\
\text { recognize the cancer cells as abnormal. So it's like the cancer cell is cloaking itself against } \\
\text { your immune system. }\end{array}$ \\
\hline & Creates a Shield & $\begin{array}{l}\text { But cancer is really smart and likes to hide from the immune system. So basically it creates } \\
\text { a shield or a way to protect itself from the immune system. }\end{array}$ \\
\hline & $\begin{array}{l}\text { Put Brakes on the } \\
\text { Immune System }\end{array}$ & $\begin{array}{l}\text { Somehow this cancer is growing in your body and it's letting it grow there. When we have } \\
\text { an infection, we have a fever, we have other things go on, and we mount the immune sys- } \\
\text { tem and we fight it off and say 'this is foreign, go away.' But for some reason these cancers } \\
\text { are growing in your body and it's okay. Somehow the cancer's able to put the brakes on } \\
\text { the immune system so it's not targeting it. }\end{array}$ \\
\hline & $\begin{array}{l}\text { Press the Off Button } \\
\text { on the Immune } \\
\text { System }\end{array}$ & $\begin{array}{l}\text { Cancer is also a foreign substance so your white cells should fight this off as well. They re- } \\
\text { alized that cancer is using some of the control buttons on the troops, on the white blood } \\
\text { cells, and is pressing the off button. Because of this reason, although the cancer cell and } \\
\text { the white cell are next to each other, they do not recognize each other. }\end{array}$ \\
\hline \multirow[t]{2}{*}{$\begin{array}{l}\text { Different Immunotherapy } \\
\text { Drugs }\end{array}$} & Jeans & $\begin{array}{l}\text { The immune therapy that has been used in the clinical trial is a drug called Pembrolizum- } \\
\text { ab, Pembro for short, or you may have heard it called Keytruda. All the same thing. There } \\
\text { is another company that makes something called Nivolumab, Nivo for short, and Opdivo is } \\
\text { that brand name. I will tell you that both drugs are the same. I describe it like two differ- } \\
\text { ent companies making a pair of jeans. They are all jeans and they all work the same. }\end{array}$ \\
\hline & Soda & $\begin{array}{l}\text { There are two on the market. There's one called Pembrolizumab. You might hear me call it } \\
\text { Pembro for short. Keytruda is the brand name. Nivolumab is the other one, called Opdivo. } \\
\text { They're Coke, Pepsi; they're the same thing. People try to tell you they're different. They } \\
\text { are subtly different, but as far as side effect profile, and you know, efficacy, really the } \\
\text { same. }\end{array}$ \\
\hline Side Effects & Paper Towel & $\begin{array}{l}\text { The Ipilimumab can cause a lot of inflammation in the colon. And think of, you know } \\
\text { when you have a paper towel and you get it really, really wet and it just breaks...that's } \\
\text { what can happen }\end{array}$ \\
\hline
\end{tabular}

only understood correctly 3 out of the 16 times (19\%) that understanding was assessed. Patients were not asked to describe the meaning of two uses of "releasing the brakes." To illustrate how cancer evades the immune system, five different metaphors were used. Most of the phrases used personification, such as describing the immune system as "blind" or cancer as having a "cloak" or "shield" to escape the immune system. To compare different immunotherapy drugs, providers compared them to different brands of "jeans" or "soda." Lastly, one provider used a "wet paper 
towel" to describe how one of the possible side effects of immunotherapy, colitis, can lead to colon rupture. Two metaphors were used by multiple providers: five providers used "rev up the immune system" and six providers used the "release the brakes." Overall, participants correctly understood what providers meant when they used metaphors 23 out of 43 times (54\%).

\section{Discussion}

Although metaphors have been commonly used in medicine to aid communication and there is extensive research on many aspects of metaphor use ${ }^{6}$, this is the first study to our knowledge that captures how metaphors are being used in clinical oncology to describe immunotherapy. Replicating a similar study conducted by Pinheiro et al. we identified fourteen metaphors used by providers to describe four immunotherapy topics. More than half of the participants correctly understood the metaphors used by providers (54\%). However, while the "releasing the brakes" metaphor was the most frequently used, it was one of the least often understood (19\%). Providers need to be conscious that understanding rates can vary depending on the specific phrase used and on how that phrase is presented.

We recognize that this is a small, qualitative study limited to a single academic institution. Most patients had at least an undergraduate degree and were white, possibly reflecting the predominance of melanoma patients. Our sample size was too small to analyze the impact of demographics. We did not collect data about each participant's previous exposure to information on immunotherapy and therefore could not definitively determine whether patient understanding was a reflection of the metaphor used or the participant's prior knowledge base.

Our intent is to provide a helpful tool for oncologists interested in improving their communication with patients about immunotherapy. Since in this study patients only understood the metaphors about half of the time, we suggest that oncologists carefully consider the metaphors they use and perhaps expand upon each metaphor by explaining the comparison. For example, for 'release the brakes,' which was infrequently understood, it could be explained that just as a truck has brakes that must be released in order to move, cancer puts brakes on the immune system so it can't move and attack the cancer. Immunotherapy releases those brakes. We do suggest, however, that as immunotherapy continues to become standard therapy for a variety of cancers, using metaphors can be a useful strategy to explain immunotherapy to cancer patients.

\section{Acknowledgments}

Research reported in this publication was supported by the Winship Cancer Institute/Davidson College Impact Fellowship under award number P30CA138292

\section{Disclosures}

Dr. Bilen has a consulting/advisory role with Exelixis, Nektar, Genomic Health, and Sanofi and receives research funding from Bayer, Bristol-Myers Squibb, Genentech/ Roche, Incyte, Nektar, AstraZeneca, Tricon Pharmaceuticals, Peleton, and Pfizer.

\section{References}

1. Farkona S, Diamandis EP, Blasutig IM. Cancer immunotherapy: the beginning of the end of cancer? Bmc Medicine. 2016; 14: 18.

2. Berkman ND, Sheridan SL, Donahue KE, et al. Low Health Literacy and Health Outcomes: An Updated Systematic Review. Annals of Internal Medicine. 2011; 155(2): 97-107.

3. Reisfield GM, Wilson GR. Use of metaphor in the discourse on cancer. Journal of Clinical Oncology. 2004; 22(19): 4024-4027.

4. Casarett D, Pickard A, Fishman JM, et al. Can Metaphors and Analogies Improve Communication with Seriously Ill Patients? Journal of Palliative Medicine. 2010; 13(3): 255-260.

5. Pinheiro APM, Pocock RH, Dixon MD, et al. Using Metaphors to Explain Molecular Testing to Cancer Patients. Oncologist. 2017; 22(4): 445449.6

6. Gibbs, RW Jr ed The Cambridge Handbook of Metaphor and Thought. Cambridge University Press New York 2008. 